\title{
In-vitro production of prostaglandins by intrauterine tissues from pregnant goats
}

\author{
M. D. Mitchell, A. P. F. Flint*, J. S. Robinson and G. D. Thorburn $\dagger$ \\ Nuffield Department of Obstetrics and Gynaecology, University of Oxford, John Radcliffe Hospital, \\ Headington, Oxford, U.K.
}

\begin{abstract}
Summary. In the fetal cotyledons and membranes, PGE production (determined in a continuous superfusion system) was significantly greater than that of PGF $(P<0.01$ and $P<0.02$ respectively). The fetal cotyledon also produced more PGE than the maternal cotyledon $(P<0.01)$ and more PGF after parturition than before $(P<0.01)$.
\end{abstract}

Parturition in many animals, including the goat, is associated with elevated plasma concentrations of prostaglandin (PG) F (Thorburn, Nicol, Bassett, Shutt \& Cox, 1972; Flint \& Hillier, 1976; Thorburn, Challis \& Currie, 1977). Although concentrations of PGF in intrauterine tissues have not been measured in the goat, high tissue concentrations have been found at parturition in ruminants (Flint \& Hillier, 1976; Thorburn et al., 1977). Such data must be interpreted with caution because manipulation of tissue is a potent stimulus for the release of PGs (Piper \& Vane, 1971). By using a continuous superfusion method (Mitchell \& Flint, 1978) to overcome this problem we have determined the possible sources of, and changes in, PG production by intrauterine tissues from periparturient goats.

\section{Materials and Methods}

Nine pregnant goats were used. The day of marking by a billy was taken as Day 0 of pregnancy. Before induction of anaesthesia (with $0.5 \mathrm{~g}$ thiopentone) the goats were given $200 \mathrm{mg}$ sodium meclofenamate intravenously to inhibit release of PG due to surgical trauma. Maternal, fetal and amniotic catheters were implanted by aseptic procedures (Challis, Dilley, Robinson \& Thorburn, 1976) between 115 and 130 days of pregnancy and some cotyledons and membranes were excised. The cotyledons were separated into maternal and fetal components and these tissues were rapidly minced into small pieces and placed in the superfusion system described by Mitchell \& Flint (1978). After operation the animals were infused with sodium meclofenamate ( $0.5 \mathrm{~g}$ on Day $1,0.3 \mathrm{~g}$ on Day 2 and $0.1 \mathrm{~g}$ on Day 3$)$. Six animals aborted despite this treatment, but the other 3 goats were left a further 3 days before dexamethasone was infused into the fetuses at the rate of $0.5-1.0 \mathrm{mg} / 24 \mathrm{~h}$. This treatment induced premature parturition within 65,59 and $65 \mathrm{~h}$ and immediately after birth fetal cotyledons and membranes were taken for superfusion. The dams were not killed and so maternal cotyledonary tissue was not available.

In the superfusion system, any PGs released by the trauma of excision and manipulation were washed out before samples were obtained under steady state conditions for measurement of PG concentrations by radioimmunoassays previously described (Mitchell, Patrick, Robinson, Thorburn \& Challis, 1976; Mitchell \& Flint, 1978). Extraction efficiencies ranged between 70 and $90 \%$ and buffer blank values were invariably $<5 \mathrm{pg}$. Intra-assay coefficients of variation were $8.9 \%$ for PGE, $13.4 \%$ for PGF and $2.5 \%$ for 13,14-dihydro-15-keto prostaglandin F.

The significance of the differences was calculated by the Wilcoxon Signed Rank Test for paired data and the Mann-Whitney Rank Sum Test for unpaired data.

* Present address: A.R.C. Institute of Animal Physiology, Babraham, Cambridge CB2 4AT, U.K.

$\dagger$ Present address: Department of Physiology, University of Queensland, St. Lucia, Brisbane, Queensland, Australia 4067. 


\section{Results}

The results are shown in Table 1. During late pregnancy PGE production by fetal cotyledons was significantly greater $(P<0.01)$ than that of maternal cotyledons, and the fetal cotyledons produced PGE and 13,14-dihydro-15-keto PGF in significantly greater quantities than PGF $(P<0.01$ and $P<0.05$ respectively). In addition, the membranes produced significantly more PGE than $P G F$ $(P<0.02)$. Myometrial PG production in 2 animals before the onset of parturition was low $(1-4$ $\mathrm{ng} / \mathrm{g}$ dry wt/min). After birth, PGF production by the fetal cotyledons was significantly increased $(P<0.01)$. Other differences between the groups were not statistically significant.

Table 1. Mean ( \pm s.d.) prostaglandin production ( $\mathrm{ng} / \mathrm{g}$ dry $\mathrm{wt} / \mathrm{min}$ ) by intrauterine tissues from periparturient goats

\begin{tabular}{|c|c|c|c|}
\hline & PGE & PGF & $\begin{array}{l}\text { 13,14-Dihydro- } \\
\text { 15-keto PGF }\end{array}$ \\
\hline \multicolumn{4}{|l|}{ At laparotomy $(\mathrm{N}=9)$} \\
\hline Maternal cotyledons & $27 \cdot 4 \pm 16 \cdot 8$ & $17 \cdot 1 \pm 7 \cdot 5$ & $19 \cdot 8 \pm 13 \cdot 7$ \\
\hline Fetal cotyledons & $76 \cdot 1 \pm 29 \cdot 4$ & $10 \cdot 6 \pm 4 \cdot 4$ & $21 \cdot 1 \pm 18 \cdot 5$ \\
\hline Membranes & $49.9 \pm 31.2$ & $10.7 \pm 5.6$ & $14.4 \pm 5.6$ \\
\hline \multicolumn{4}{|l|}{ At parturition $(\mathrm{N}=3)$} \\
\hline Fetal cotyledons & $139 \cdot 0 \pm 40 \cdot 7$ & $19 \cdot 3 \pm 2 \cdot 7$ & $29.8 \pm 17.0$ \\
\hline Membranes & $30.7 \pm 9.8$ & $4 \cdot 7 \pm 2 \cdot 7$ & $10.9 \pm 6.4$ \\
\hline
\end{tabular}

\section{Discussion}

Novy, Piasecki \& Jackson (1974) have suggested that PGE is involved in the control of fetal haemodynamics. Our finding of substantial PGE production by the goat fetal placenta and similar results from sheep (Mitchell \& Flint, 1978) indicate that PGE in the fetal circulation is of placental origin. The trend for increased production of PGs by the fetal cotyledon and decreased production by the membranes at parturition implicates the fetal cotyledon rather than the membranes as the source of the increased plasma PG levels found at term (Thorburn et al., 1972). However, the maternal cotyledon and the myometrium are other possibilities that require investigation.

We thank Mrs E. J. Kingston, Miss I. C. McMillen and Mrs L. Clover for assistance. The work was was supported by the M.R.C. and G.D.T. is a member of the M.R.C. External Scientific Staff.

\section{References}

Challis, J.R.G., Dilley, S.R., Robinson, J.S. \& ThorbuRN, G.D. (1976) Prostaglandins in the circulation of the fetal lamb. Prostaglandins 11, 1041-1052.

Flint, A.P.F. \& Hillier, K. (1976) Prostaglandins and reproductive processes in female sheep and goats. In Prostaglandins and Reproduction, pp. 271-308. Ed. S. M. M. Karim. M. T. P. Press, Lancaster.

Mitchell, M.D. \& Flint, A.P.F. (1978) Prostaglandin production by intrauterine tissues from periparturient sheep: use of a superfusion technique. $J$. Endocr. (in press).

Mitchell, M.D., Patrick, J.E., Robinson, J.S., Thorburn, G.D. \& Challis, J.R.G. (1976) Prostaglandins in the plasma and amniotic fluid of rhesus monkey during pregnancy and after intrauterine fetal death. J. Endocr. 71, 67-76.
Novy, M.J., Piasecki, G. \& Jackson, B.T. (1974) Effect of prostaglandin $E_{2}$ and $F_{2 \alpha}$ on umbilical blood flow and fetal hemodynamics. Prostaglandins 5, 543-555.

PiPer, P.J. \& VANe, J.R. (1971) The release of prostaglandins from lung and other tissues. Ann. N.Y. Acad. Sci. 180, 363-385.

Thorburn, G.D., Nicol, D., BassetT, J.M., ShutT, D.A. \& Cox, R.I. (1972) Parturition in the goat and sheep; changes in corticosteroids, progesterone, oestrogens and prostaglandin F. J. Reprod. Fert., Suppl. 16, 61-84.

Thorburn, G.D., Challis, J.R.G. \& Currie, W.B. (1977) Control of parturition in domestic animals. Biol. Reprod. 16, 18-27. 